\title{
How Retinal Microcircuits Scale for Ganglion Cells of Different Size
}

\author{
Christian K. Kier, ${ }^{1}$ Gershon Buchsbaum, ${ }^{1}$ and Peter Sterling ${ }^{2}$ \\ Departments of ${ }^{1}$ Bioengineering and ${ }^{2}$ Neuroscience, University of Pennsylvania, School of Medicine, Philadelphia, \\ Pennsylvania 19104
}

\begin{abstract}
Ganglion cell receptive field centers are small in central retina and larger toward periphery. Accompanying this expansion, the distribution of sensitivity across the centers remain Gaussian, but peak sensitivities decline. To identify circuitry that might explain this physiology, we measured the density of bipolar cell synapses on the dendritic membrane of beta $(X)$ and alpha $(Y)$ ganglion cells and the distribution of dendritic membrane across their dendritic fields. Both central and peripheral beta cells receive bipolar cell synapses at a density of $\sim 28 / 100 \mu \mathrm{m}^{2}$ of dendritic membrane; central and peripheral alpha cells receive $\sim 13$ / $100 \mu \mathrm{m}^{2}$. The distribution of dendritic membrane across the dendritic field is dome-like; therefore, the distribution of bipolar cell synapses is also dome-like. As the dendritic field enlarges, total postsynaptic membrane increases with field radius, but only linearly. Consequently, density of postsynaptic membrane in the dendritic field declines, and so does density of synapses within the field. The results suggest a simple model in which the receptive field center's Gaussian profile and peak sensitivity are both set by the density of bipolar cell synapses across the dendritic field.
\end{abstract}

[Key words: alpha $(Y)$ cell, beta $(X)$ cell, synaptic density, neural sensitivity, neural computation, receptive field]

In sensory systems to reconstruct an image from spatial samples requires at least two samples/spatial cycle (Nyquist's theorem, e.g., Williams, 1992). Consequently, high acuity requires fine sampling, and thus many neurons with small receptive fields. Since fine sampling is so costly, it is commonly restricted to small, specialized regions (the finger tip, the fovea), while the general sensory surface covers vast territory with fewer but larger neurons. This architecture poses a challenge to neural circuitry: how to maintain the physiological properties of a given cell type over orders of magnitude shift in scale?

Our particular example concerns ganglion cells in cat retina where a central beta $(X)$ cell spans $\sim 20 \mu \mathrm{m}$ and a peripheral cell of the same type spans $\sim 200 \mu \mathrm{m}$ (Boycott and Wässle, 1974). The wide dendritic field covers 100 -fold greater area than the narrow one and encompasses about 10-fold more cones (Tsukamoto et al., 1990). Yet, the excitatory centers of both receptive

Received May 9, 1995; revised July 11, 1995; accepted July 26, 1995

We thank Dennis Dacey for instruction in intracellular injection of Neurobiotin and Barbara McGuire, Michael Freed, Ethan Cohen, and Noga Vardi for contributing material for analysis. We also thank Sally Shrom for performing the electron microscopy and Robert G. Smith and Michael Freed for raising the problem. This work was supported by EY 00828.

Correspondence should be addressed to Peter Sterling, Department of Neuroscience, University of Pennsylvania, Philadelphia, PA 19104-6058.

Copyright $\odot 1995$ Society for Neuroscience $0270-6474 / 95 / 157673-11 \$ 05.00 / 0$ fields show linear spatial summation and Gaussian distributions of sensitivity (Rodieck and Stone, 1965; Enroth-Cugell and Robson, 1966; Cleland et al.,1979; Peichl and Wässle, 1979; Linsenmeier et al., 1982). This is also true for the alpha (Y) ganglion cell from center to periphery that spans $150-800 \mu \mathrm{m}$. The main difference between small and large cells is that the larger ones have lower peak sensitivity (Wiesel, 1960; Peichl and Wässle, 1979; Linsenmeier et al., 1982). The decline in sensitivity for larger beta cells is dramatic, about 10-fold; whereas for alpha (Y) cells it is modest, about twofold. We have investigated microcircuitry that might account for these properties of the receptive field center, its Gaussian-like form, and its characteristic peak sensitivity.

In central cat retina, these circuits have been reconstructed at the electron microscope level. Thus, it is known that a beta cell collects from 36 cones via $\sim 150$ bipolar cell synapses (Cohen and Sterling, 1991, 1992), and that an alpha cell collects from 600 cones via $\sim 540$ bipolar cell synapses (Freed and Sterling, 1988). However, beyond the central area such quantitative information is unavailable because, as neurons get larger, determining their circuitry purely by electron microscopy becomes progressively more difficult. Therefore, we employed an indirect approach. First, we determined at a peripheral locus the distribution density of bipolar cell synapses to short segments of beta and alpha dendrites. This was done with serial EM sections. Next, we determined for several peripheral loci the distribution of dendritic membrane for beta and alpha cells that had been filled with Neurobiotin. This was done with serial optical sections. Then, we could calculate how bipolar cell synapses to a given type of ganglion cell vary over an order of magnitude shift in dendritic field diameter. Several basic features of the receptive field center seem to be explained simply by the distribution of postsynaptic membrane across the dendritic field.

\section{Materials and Methods}

Electron microscopy. A cat was deeply anesthetized with pentobarbital $(40 \mathrm{mg} / \mathrm{kg})$ and then perfused with a phosphate-buffered $(0.1 \mathrm{M})$ mixture of $2 \%$ glutaraldehyde and $2 \%$ paraformaldehyde. A piece of temporal retina was cut from the horizontal meridian at $9^{\circ}$ eccentricity. This piece was postfixed in osmium tetroxide $\left(2 \% \mathrm{OsO}_{4}\right.$ in $5 \%$ phosphate-buffered sucrose), stained en bloc with uranyl acetate $(1 \%$ in $70 \% \mathrm{MeOH})$, dehydrated $(\mathrm{McOH})$, and cmbedded in Epon betwecn two plastic slides. This piece was sectioned tangentially from the ganglion cell layer through the inner plexiform layer. We collected serially 360 ultrathin sections $(0.09 \mu \mathrm{m})$, stained them additionally in uranyl acetate and lead citrate, and photographed sections at $2000 \times$ in an electron microscope.

Alpha and beta cell dendrites were identified by their cytological features known from previous studies (McGuire et al., 1986; Freed and Sterling, 1988; Cohen and Sterling, 1992). We traced their profiles from successive sections onto mylar sheets aligned on a cartoonist's jig, digitized the outlines, and reconstructed the dendritic segments by computer (Smith, 1987). Membrane surface area of a dendritic segment was 


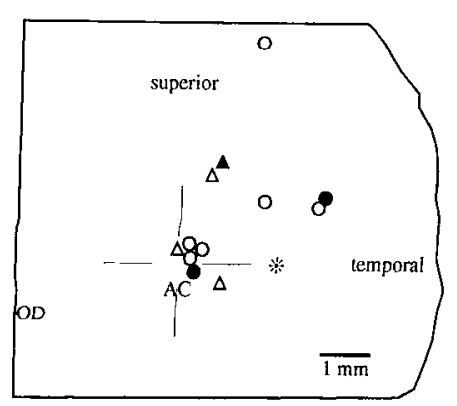

Figure l. Retinal location of reconstructed ganglion cells $(\mathrm{O}, \mathbf{O}, \mathrm{ON}$ and OFF-beta; $\triangle, \boldsymbol{\Lambda}, \mathrm{ON}$ and $\mathrm{OFF}-$ alpha) and dendritic segments $\left({ }^{*}\right)$ studied by electron microscopy.

calculated automatically as the perimeter of each profile times the nominal section thickness, summed over all the sections. For additional technical details, consult Stevens et al. (1980a) and Smith (1987).

Filling ganglion cells. We followed the procedures developed by Tauchi and Masland (1985) and Vaney (1991), as modified by Dacey and Brace (1992). A cat was deeply anesthetized and the eyes enucleated, following which the animal was killed by overdose of anesthetic. The eyes were hemisected, drained of vitreous, and immersed in oxygenated Ames medium (Sigma Chemical Co., St. Louis, MO). The retina was separated from the choroid, mounted on filter paper (ganglion cell side up), and superfused with oxygenated Ames medium.

A retina was stained with $3 \mu \mathrm{M}$ acridine orange to visualize the ganglion cell somas under epi-fluorescence. Glass microelectrodes were filled with either $4 \%$ rhodamine-labeled horseradish peroxidase (HRP; Sigma) in $20 \mathrm{~mm}$ MOPS buffer or $4 \%$ Neurobiotin (Vector) in $0.1 \mathrm{M}$ Tris buffer with $1 \%$ Lucifer yellow (Sigma) added to visualize the electrode tip. Dye was injected with $\sim 5 \mathrm{nA}$ positive current for about 1 min. A retina was injected in this way for about $3 \mathrm{hr}$, equilibrated for $1 \mathrm{hr}$, and then fixed in phosphate-buffered $(0.1 \mathrm{M}) 4 \%$ paraformaldehyde for at least $2 \mathrm{hr}$. After fixation, the retina was rinsed and processed as follows. For HRP-filled cells: incubate with agitation in $0.05 \%$ diaminobenzidine (DAB) in $0.1 \mathrm{M} P B$ for $20 \mathrm{~min}$, incubate in $0.05 \% \mathrm{DAB}$ $+0.02 \%$ hydrogen peroxide in $0.1 \mathrm{M} \mathrm{PB}$ for $15 \mathrm{~min}$, and rinse. For Neurobiotin filled cells: incubate with agitation in $0.5 \%$ Triton-X 100 (Sigma) in $0.1 \mathrm{M} \mathrm{PB}$ for $4 \mathrm{hr}$, rinse, incubate for $2 \mathrm{hr}$ in ABC complex (elite ABC kit Amersham), rinse, process as for HRP. In some cases, the DAB reaction was intensified by nickel-cobalt (Adams, 1981), and in other cases the reaction product itself was enhanced by a $10 \mathrm{~min}$ exposure to osmium vapor (a drop of $3 \%$ osmium in a covered Petri dish). The retina was mounted in $100 \%$ glycerin to avoid the shrinkage accompanying dehydration and coverslipped.

Measuring dendritic surface area. A filled cell was viewed through an oil immersion objective $(100 \times, 1.32 \mathrm{NA})$ using a matched condenser (1.32 NA). These optics produced optical sections about $2 \mu \mathrm{m}$ thick (half-maximum at full width). Section thickness was measured by capturing serial images $(0.25 \mu \mathrm{m}$ steps in depth) of a small fluorescent bead $(0.02 \mu \mathrm{m}$ diameter), normalizing the optical density observed at the center of the bead in each image, and plotting this against axial distance. Images were captured with a $512 \times 512$ pixel CCD camera with eight-bit precision and stored on optical disk. A precision stage controlled by computer allowed adjacent regions to be captured as a montage. Files of serial optical sections were transferred to a workstation (SGI Indigo) where the intensity range covered by an image was normalized to values between $0-255$ and printed at $600 \mathrm{dpi}$ on a laser printer. From these prints, the dendritic profiles in each section were digitized (Smith, 1987) and the surface area of the dendritic arbor was calculated as described above.

\section{Results}

Distribution density of bipolar cell synapses on peripheral alpha and beta dendrites

The tissue for electron microscopy was taken $2 \mathrm{~mm}\left(9^{\circ}\right) \mathrm{tem}$ poral to the center of the area centralis on the horizontal meridian (Fig. 1). We identified bipolar cell synapses by their presynaptic ribbons (Fig. 2; Dowling and Boycolt, 1965), alpha dendrites by their large caliber and pale cytoplasm (Fig. $2 A$ ), and beta dendrites by their finer caliber and dark cytoplasm (Fig. $2 B$; Kolb, 1979; Stevens et al., 1980b; McGuire et al., 1986).

In single sections, beta dendrites but not alpha dendrites commonly received several bipolar cell synapses (Fig. 2). This suggested a greater density of bipolar cell synapses on the beta cell membrane, and this was confirmed by reconstructing dendritic segments (Fig. 3). The distribution of bipolar cell synapses to $O N$ beta and OFF beta dendritic segments were similar (respectively, 24 and 34 synapses per $100 \mu^{2}$ membrane), and this average came to 28.2 bipolar cell synapses $/ 100 \mu \mathrm{m}^{2}$ membrane. The distributions of bipolar cell synapses to ON alpha and OFF alpha dendritic membrane were also similar to each other (respectively, 9 and 16 synapses/100 $\mu^{2}$ of membrane), and their average came to 13 synapses $/ 100 \mu \mathrm{m}^{2}$. The ratio of bipolar synaptic densities on the beta versus alpha membrane was 2.2. Wc compared this data at $9^{\circ}$ eccentricity to that for ON and OFF beta and alpha cells at $1^{\circ}$.

The densities at $1^{\circ}$ were calculated from data provided by several previous studies at the EM level from this laboratory (McGuire et al. 1986; Freed and Sterling, 1988; Cohen and Sterling, 1992; Vardi, unpublished). In two different cats bipolar cell synapses distributed similarly to ON and OFF beta dendrites (27 and 29 synapses $/ 100 \mu \mathrm{m}^{2}$ ), virtually identical to the beta dendrites at $9^{\circ}$. In three different cats bipolar cell synapses distributed similarly to ON and OFF alpha cell dendrites ( 9 and 12 synapses $/ 100 \mu \mathrm{m}^{2}$ ), highly similar to the alpha dendrites at $9^{\circ}$.

These comparisons suggest several important conclusions: (1) within the same class (beta or alpha) bipolar synaptic densities are similar for ON and OFF cells; (2) within the same class bipolar synaptic densities are similar for different cats and for different eccentricities; (3) bipolar synaptic densities on beta cells are $\sim$ twofold greater than on alpha cells. Since there is apparently no shrinkage in such material (Tsukamoto et al., 1992: McGuire and Sterling, unpublished), these comparisons between different animals can stand without correction. Equally important, this information from electron microscopy can be directly compared to the light microscope studies of the distribution of ganglion cell dendritic membrane.

\section{Distribution of postsynaptic membrane across ganglion cell dendritic field}

The constant density of bipolar cell synapses on the ganglion cell dendritic membrane implies that the distribution of synapses across the dendritic field would correspond to the distribution of dendritic membrane. We reconstructed the distribution of dendritic membrane for beta and alpha cells at $9-21^{\circ}$ eccentricity (Fig. 1) from optical sectio:s cut tangentially. One set of such optical sections, each representing a $2 \mu \mathrm{m}$ slice through a beta cell, is shown in Figure 4. Such sections through a complete dendritic tree were stacked in register to produce the reconstructions shown in Figure 5. Somas and proximal dendrites were omitted because they receive no bipolar cell synapses (Kolb, 1979; Stevens et al., 1980b). We also quantified the distribution of dendritic membrane for cells at $1^{\circ}$ by similarly stacking images from EM sections cut radially. In Figure 5, these cells are shown rotated into tangential view. The light microscope material was mounted in glycerol, and thus avoiding the shrinkage that accompanies dehydration, while the material prepared as described for EM also shows no shrinkage (Tsukamoto et al., 1992; McGuire, unpublished). Since neither method produces shrinkage, the two sets of reconstructions are directly comparable. 

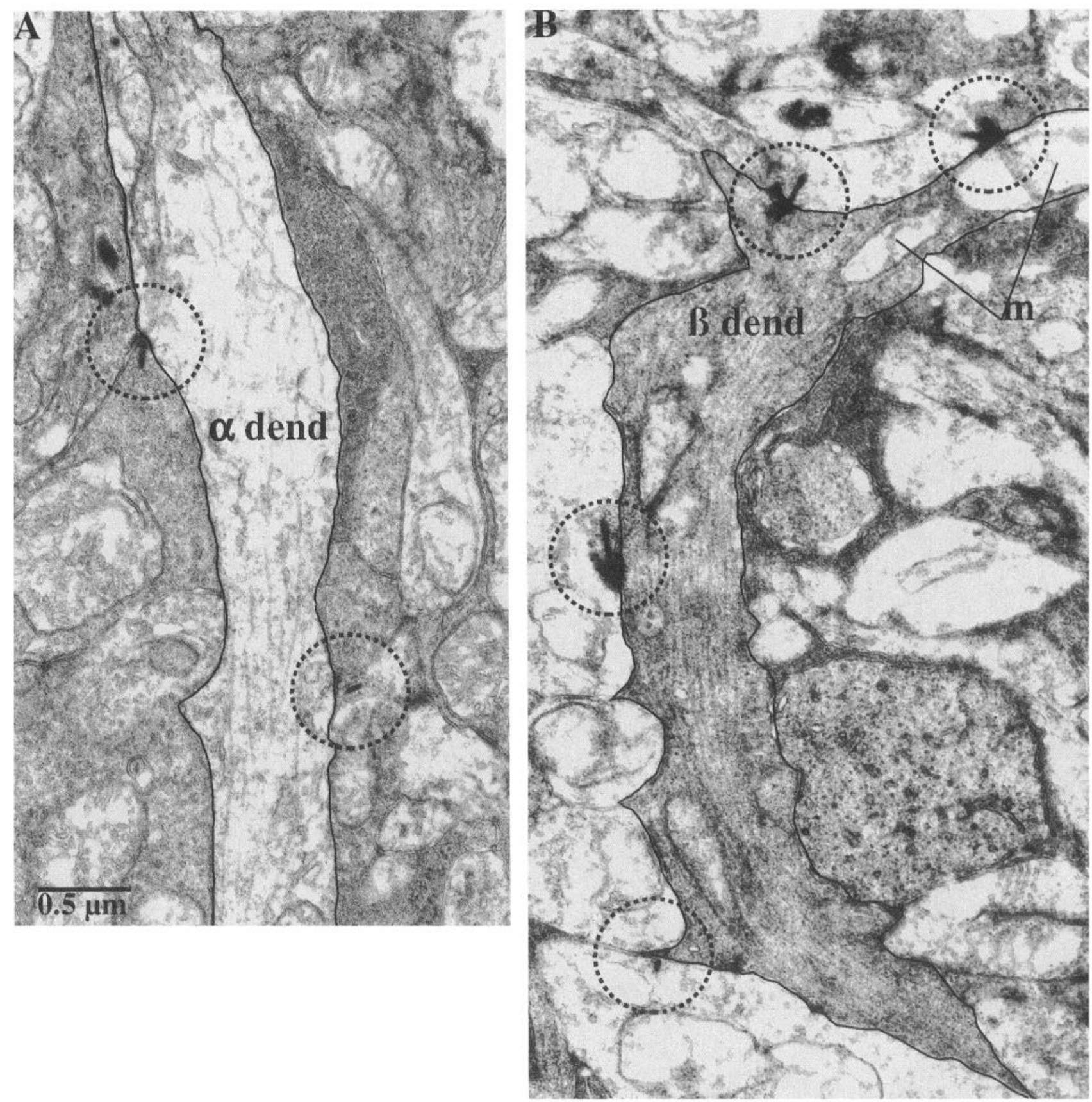

Figure 2. A, Bipolar cell synapses marked by presynaptic ribbons contact pale alpha dendrite. $B$, Bipolar cell synapses contact dark beta dendrite. Same magnification for $A$ and $B$. Bipolar cell synapses are more densely distributed to beta dendrites. $m$, mitochondrion.

Figure 5 confirms what is long established, that from central to peripheral retina the dendritic fields of both cell classes enlarge and that beta dendritic fields branch densely in central retina but more sparsely in peripheral retina. However, these quantitative reconstructions of postsynaptic membrane lead to several new points. First, for alpha and beta cells alike, branching is much greater near the center of the dendritic field than at the edge (Fig. 6).

Second, the distribution of postsynaptic membrane across the field is dome-like. This is evident in Figure $7 A$, which plots the absolute distribution of membrane across the field of each cell. The alpha cells, being much broader, express more total postsynaptic membrane, but the curves are all rather similar. After averaging and normalizing, the distributions for alpha and beta cells are virtually identical (Fig. $7 B$ ).

We noted that dendrites of directionally selective ganglion cells (rabbit) maintain their density of branching even toward the edge of the dendritic field (Vaney, 1994; Yang and Masland, 1994) - apparently differing from alpha and beta cells. To quantify this observation, we digitized the dendritic tree of one such cell (Fig. 4 from Yang and Masland, 1994). Assuming that dendritic membrane area is proportional to dendritic length (reasonable, given the minor contribution of taper), the membrane distribution is virtually flat across the dendritic field (Fig. 7B). This distribution of membrane correlates with the flat distribution of sensitivity across the receptive field noted qualitatively by Yang 


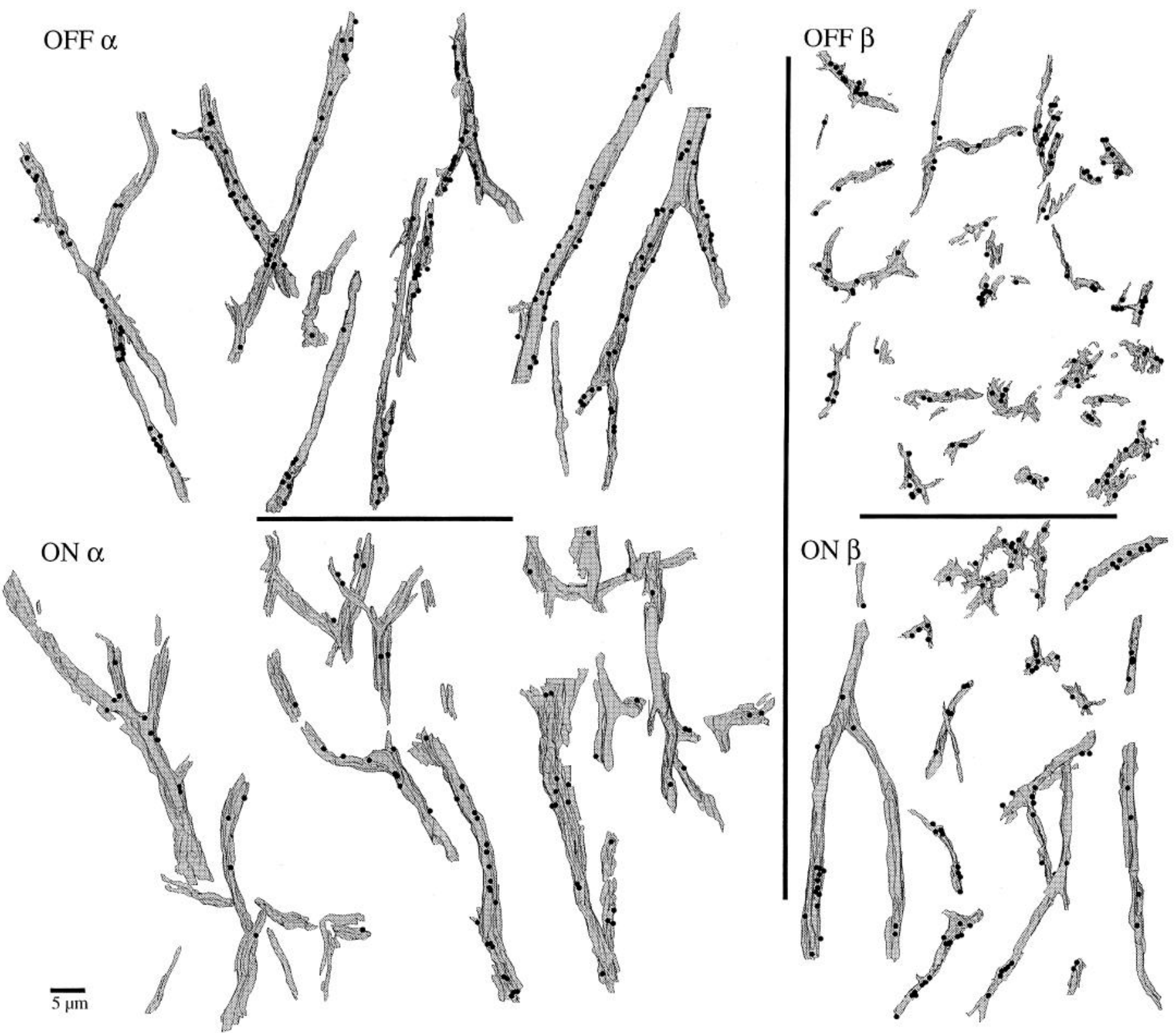

Figure 3. Reconstructions from electron micrographs of tangential serial sections of alpha and beta dendritic segments showing location of bipolar cell synapses $(\mathbf{O})$.

and Masland (1994) and measured by He (1994). Thus, the dome-like distribution of beta and alpha cell membrane appears to be a definite contribution to the coding scheme (Tsukamoto et al., 1990; Tsukamoto and Sterling, 1991), rather than a mere default feature common to all ganglion cell types.

\section{Amount of postsynaptic membrane for cells of different size}

From central to peripheral retina beta dendritic fields increase about 10 -fold in diameter $(20-200 \mu \mathrm{m})$, reaching asymptote at about $4 \mathrm{~mm}$ (Fig. 5B; Figure 8 in Boycott and Wässle, 1974). To maintain postsynaptic membrane in the dendritic field at constant density, membrane area would need to rise as the square of the radius, that is, 100 -fold. However, postsynaptic membrane did not keep up this pace, but rose linearly and reached asymptote at about $2 \mathrm{~mm}\left(8.8^{\circ}\right)$ eccentricity for fields about $100 \mu \mathrm{m}$ diameter. Thereafter, though the field enlarged modestly, up to
$170 \mu \mathrm{m}$ diameter at $4.6 \mathrm{~mm}\left(21^{\circ}\right)$, postsynaptic membrane area was essentially constant. Overall, postsynaptic membrane/cell increased only 12 -fold, from about $550 \mu \mathrm{m}^{2}$ for the narrowest fields up to about $6500 \mu \mathrm{m}^{2}$ for the broadest (Fig. $8 A$ ). Consequently, the density of postsynaptic membrane in the dendritic field (membrane area/field area) fell sharply from about 1 to 0.29 (Fig. $8 B$ ).

From central to peripheral retina alpha dendritic fields increase about fourfold in diameter $(200-800 \mu \mathrm{m})$, reaching asymptote at about $8 \mathrm{~mm}$ (Fig. 5A; Figure 7 in Boycott and Wässle, 1974). To maintain postsynaptic membrane in the dendritic field at constant density, membrane area would need to rise 16fold. However, again the increase in postsynaptic membrane did not keep up with the increase in field diameter, but rose linearly and reached asymptote (at least for the ON cells) at about $2 \mathrm{~mm}$ $\left(8.8^{\circ}\right)$ for a field diameter of about $400 \mu \mathrm{m}$. Overall, postsyn- 

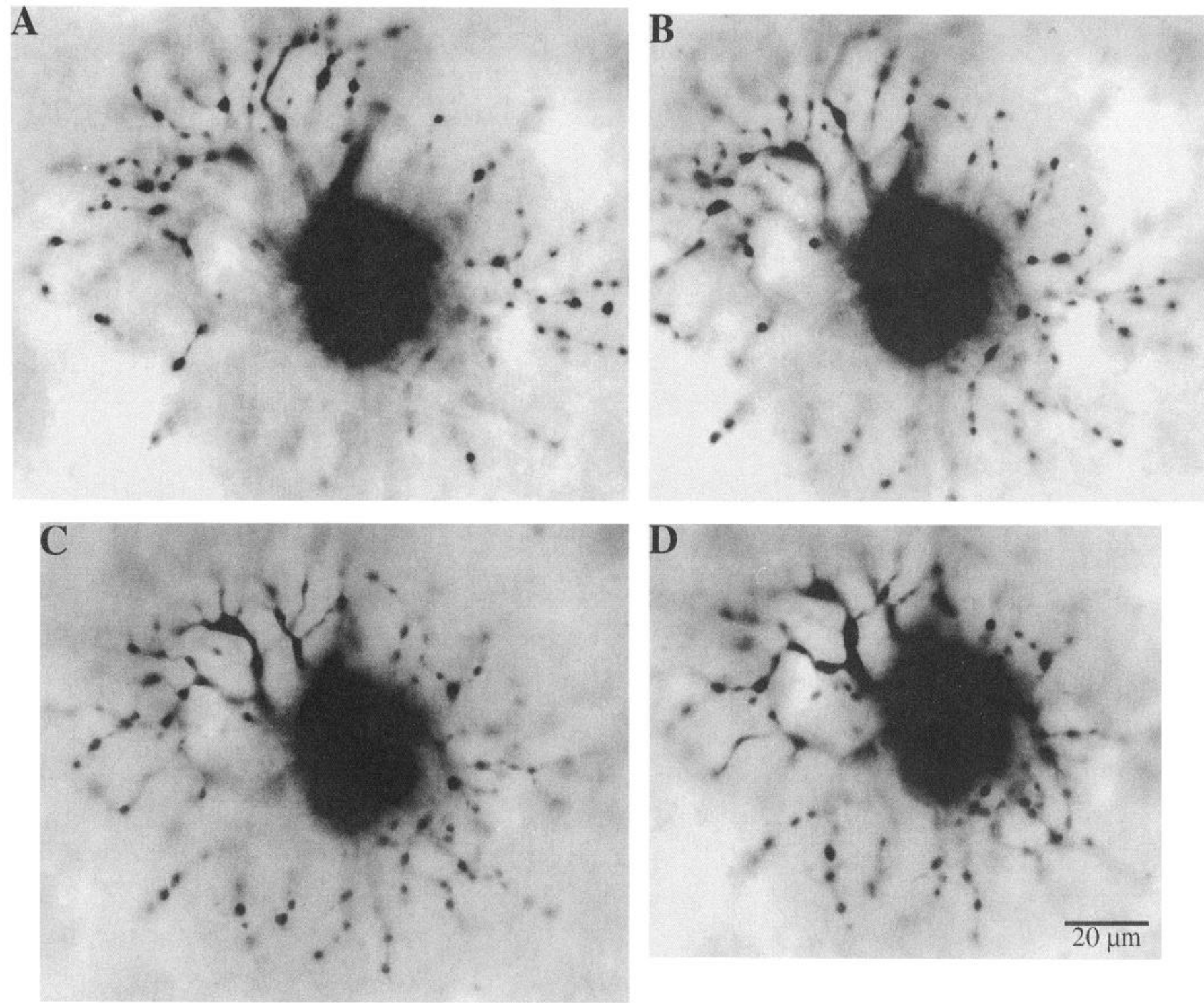

Figure 4. Optical sections through peripheral beta cell (about $9^{\circ}$ eccentricity). Sections $A$ through $D$ progress from distal to proximal dendrites. Sections were taken with $100 \times$, NA 1.32 objective; they are approximately $2 \mu \mathrm{m}$ thick and spaced $2 \mu \mathrm{m}$ apart.

aptic membrane/cell increased only sevenfold, from about 5100 $\mu \mathrm{m}^{2}$ for the narrowest field to about $37,500 \mu \mathrm{m}^{2}$ for the broadest (Fig. 8). The density of postsynaptic membrane for alpha cells was much lower than for beta cells at the same retinal locus, and the decrease in density with eccentricity was modest (Fig. $7 B$ ). For an alpha and beta cell of the same field diameter, membrane density was the same (Fig. $8 B, C$ ).

Since cone density declines from center to periphery (Steinberg et al., 1973; Williams et al., 1993), we considered whether membrane density (proportional to synaptic density) in a dendritic field might be related to local cone density. This relationship is complicated. Both cone density and synaptic density are high for central beta cells and fall with increasing dendritic field diameter. But for central alpha cells, cone density is high while synaptic density is low. Furthermore, as cone density falls, alpha cell synaptic density changes relatively little. Thus, synaptic density in the dendritic field and local cone density are not related in any simple way.

\section{Discussion}

Density of bipolar cell synapses on the dendritic membrane is constant for each cell type

Density of bipolar cell synapses on the postsynaptic membrane for $\mathrm{ON}$ and $\mathrm{OFF}$ beta cells is about $28 / 100 \mu \mathrm{m}^{2}$ of dendritic membrane, and for ON and OFF alpha cells it is about half that, $13 / 100 \mu \mathrm{m}^{2}$. The figures are the same for the full dendritic trees reconstructed at $1^{\circ}$ eccentricity as for dendritic segments reconstructed at $9^{\circ}$. Further, the results for alpha cells accumulated now from four different animals and for beta cells from three different animals were the same. This is consistent with other evidence that, for a given locus in mammalian retina, the numbers of input and output synapses for a specific cell type are highly constant (McGuire et al., 1984; Freed and Sterling, 1988; Cohen and Sterling, 1990, 1992; Calkins et al., 1994; Rao-Mirotznik et al., 1995). The present results also suggest that density of synapses on the membrane of a given cell type is constant 


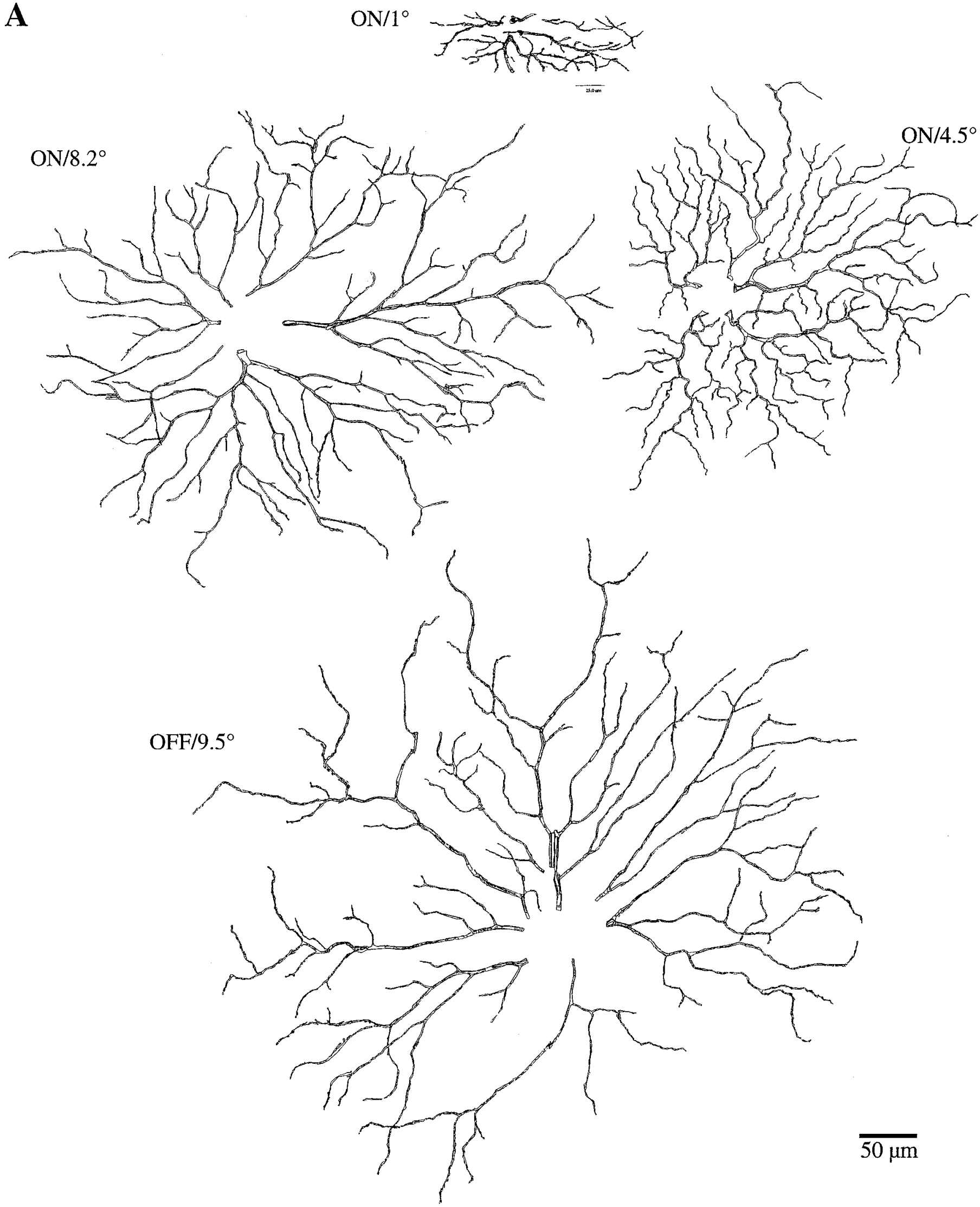

Figure 5. Reconstructions of ganglion cell postsynaptic membrane from serial sections. $A$, Alpha cells; $B$, beta cells. (Note differenl scales.) Cells at $1^{\circ}$ eccentricity are from EMs of radial, ultrathin sections; alpha cell at $1^{\circ}$ only $40 \%$ complete (see Freed and Sterling, 1988). Cells beyond the central area are from tangential, optical sections (see Fig. 4). Somas and proximal dendrites were omitted because they do not receive bipolar cell. synapses. Note that the regions overlying the soma and proximal dendrites are devoid of higher order branches from the same cell. In this respect they differ from direction-sensitive ganglion cells (Vaney, 1994; Yang and Masland, 1994). 
B

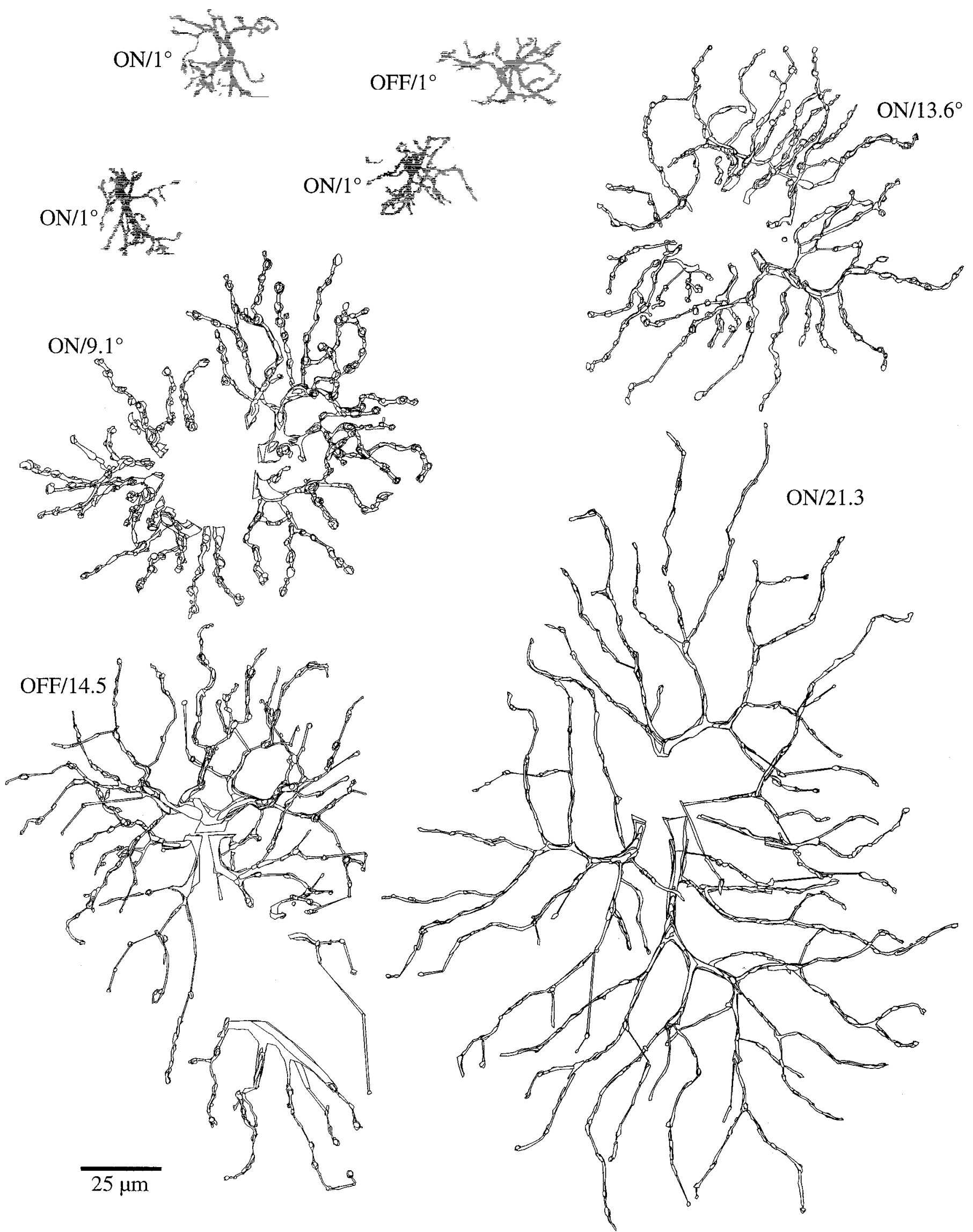

Figure 5. Continued. 


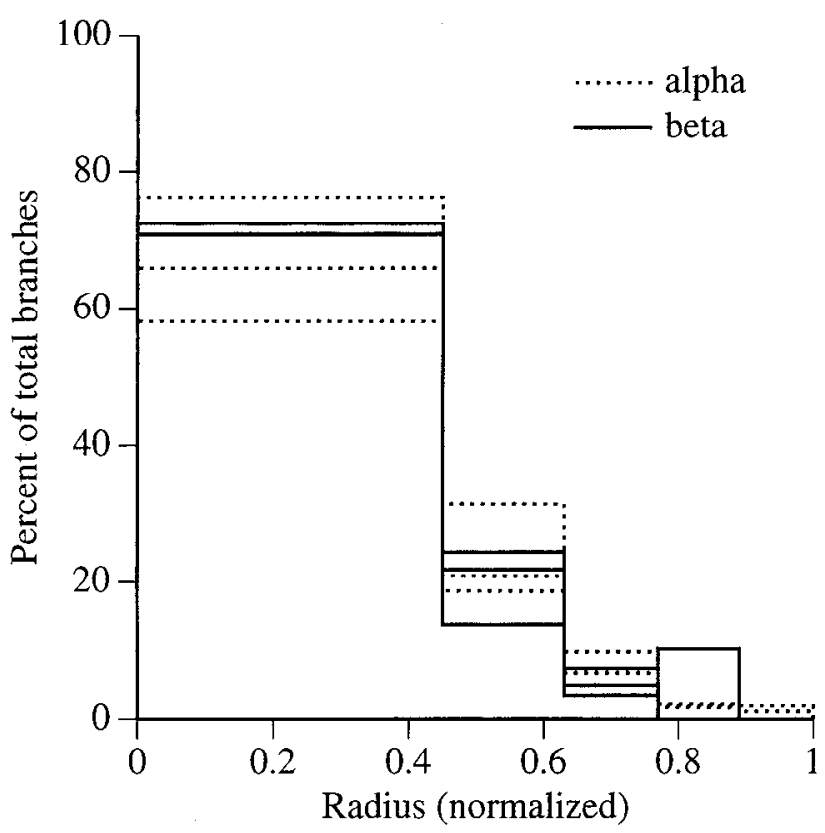

Figure 6. Location of branch points in the dendritic fields of three alpha and three beta cells. For each cell the number of branches were counted within concentric annuli encompassing the dendritic field. The counts, when normalized, show that for both cell types about $60-80 \%$ of the branches arose within the central half of the dendritic field.

across the retina. To prove this beyond all doubt would require EM data from additional retinal loci. However, given the similarity at two loci for each of four cell types, the substantial effort to analyze even one nore site did not seem justified. The calculations to follow assume constancy.

\section{Receptive field center corresponds to dendritic field}

Our hypothesis to explain ganglion cell sensitivity builds upon the idea that the receptive field center is due to excitation from neurons immediately overlying (cospatial with) the dendritic field. This is consistent with our earlier studies of ganglion cell circuitry (e.g., McGuire et al., 1986; Freed and Sterling, 1988; Sterling et al., 1988; Cohen and Sterling, 1992). It is also supported by many comparisons of physiology to morphology: the receptive field center generally matches the dendritic field, the receptive field center being slightly larger than the dendritic field (Peichl and Wässle, 1979, 1983; Yang and Masland, 1994). All these recordings were extracellular, and the comparisons to morphology were either to dendritic fields in other retinas (e.g., Peichl and Wässle, 1979, 1983) or to the dendritic field of the same ganglion cell following its postrecording penetration and filling with Lucifer yellow (Pu et al., 1994; Yang and Masland, 1994). Yet, certain studies find the receptive field center to be smaller than the dendritic field and find no correlation between them (Stanford, 1987; Nelson et al., 1993). In these studies, the ganglion cells were first penetrated and then mapped. If a cell were even slightly damaged by penetration (as suggested by the modest spike amplitudes), its response to the least sensitive regions of the center might drop below threshold for mapping. Thus, for comparison to morphology, the extracellular recordings are probably more reliable.

Sensitivity across receptive field set by distribution of synapses across dendritic field

A key point emerging from the present study is that the distribution of postsynaptic membrane across the ganglion cell den-
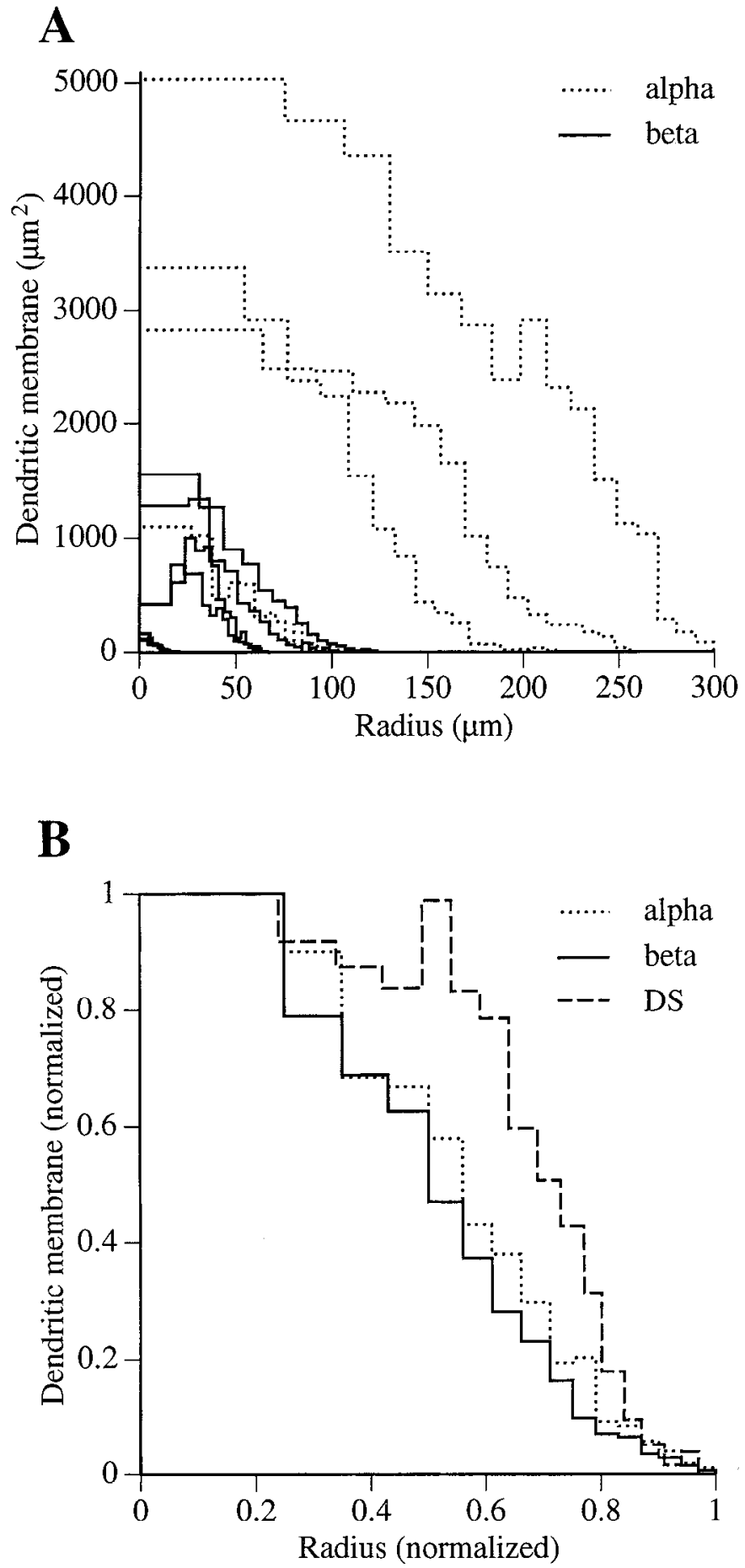

Figure \% Distribution of postsynaptic membrane for cells of different dendritic field size. A, Vertical axis, membrane area at center dendritic field and successive annuli of equal area. Horizontal axis, radius of annuli. All curves are similar. $B$, Alpha cell and beta cell curves averaged and normalized for field size are virtually identical. Curve for one DS cell digitized from Figure 4 of Yang and Masland (1994), normalized for field size shows a membrane density across the field that is markedly flat. Thus, at half the field radius, membrane density for alpha and beta cells falls by half, while for the DS cell it is unchanged.

dritic field is dome-like. Because the distribution of bipolar cell synapses on the dendritic membrane is relatively even and is the same for all orders of dendritic branching (Fig. 3; McGuire et al., 1986; Freed and Sterling, 1988; Weber et al., 1991; Cohen 
A

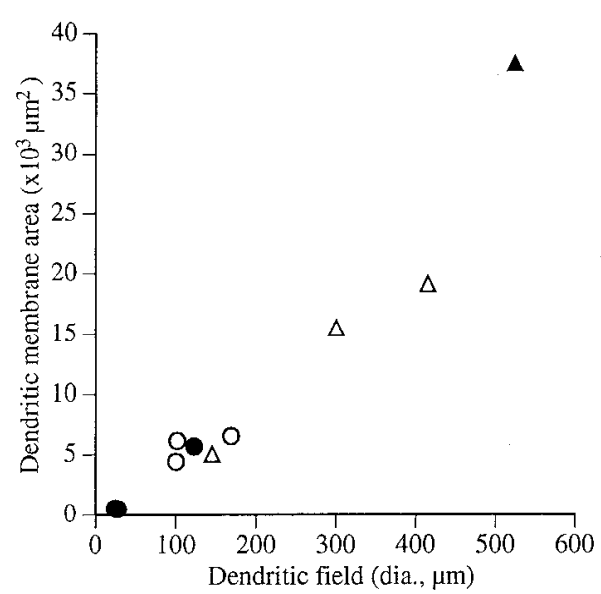

B

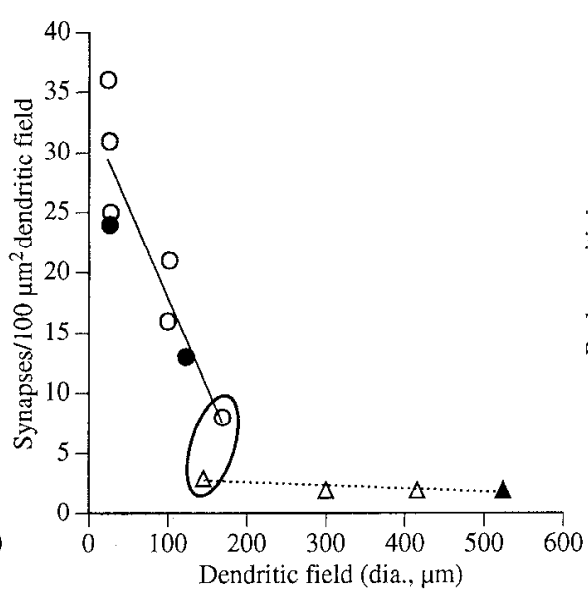

C

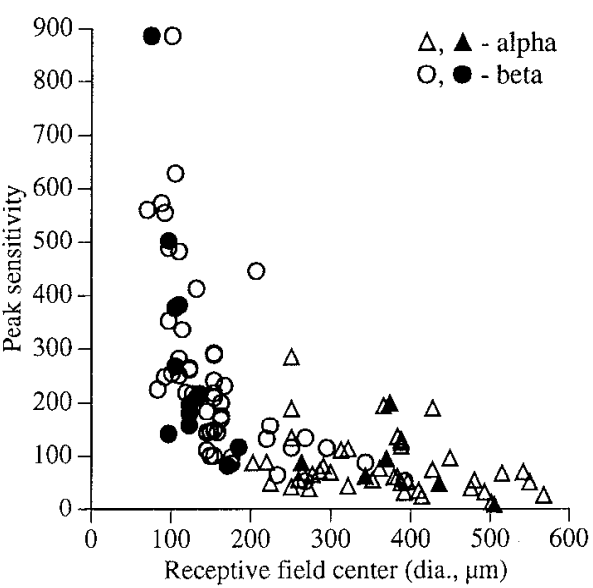

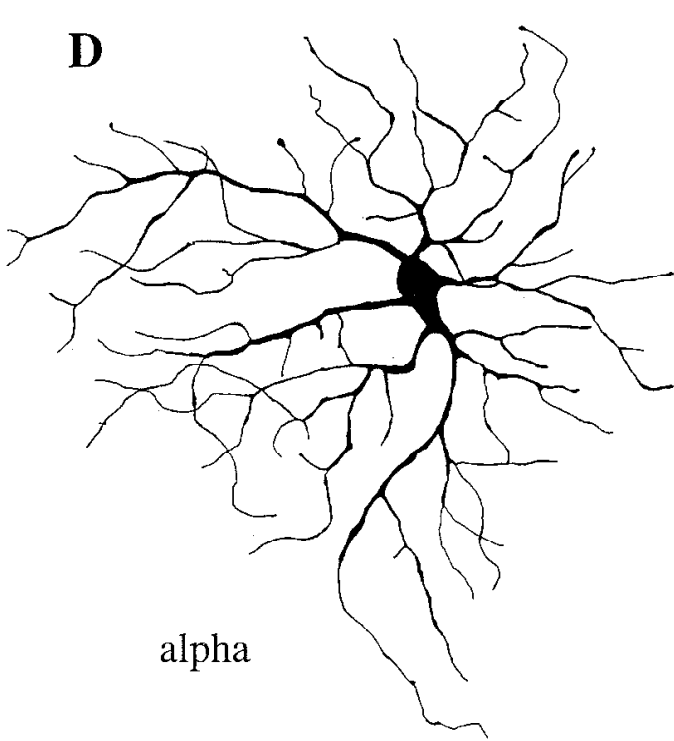

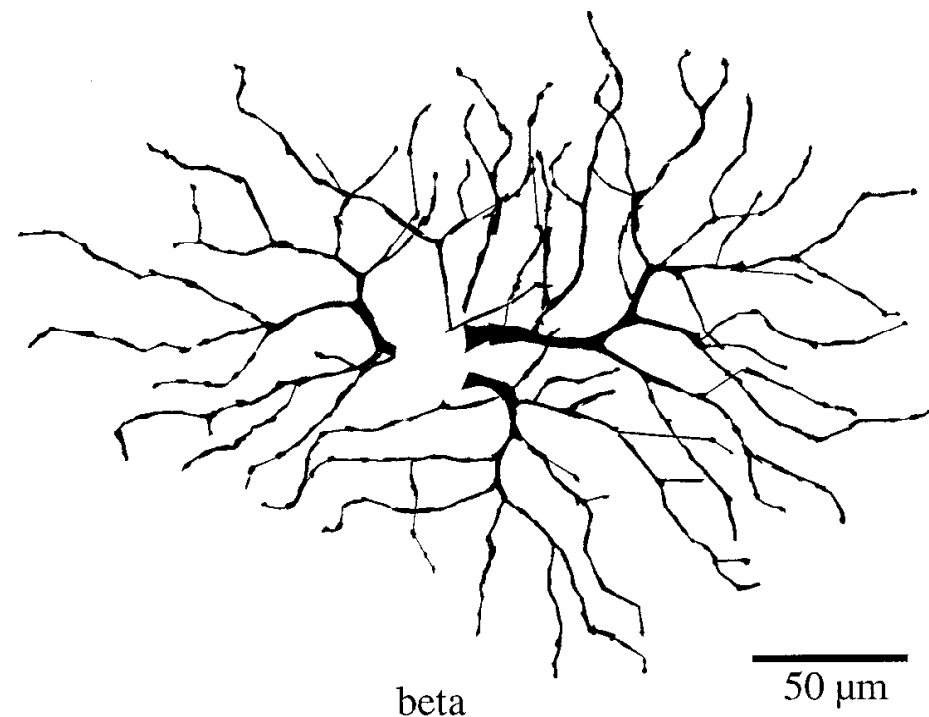

Figure 8. $A$, Total membrane area per cell is linear with field diameter but aymptotes for beta cells at $\sim 100 \mu \mathrm{m}$. $B$, Synaptic density versus dendritic field diameter. The plots in $B$ and $C$ are virtually identical. For center diameters of 200-375 $\mu$ mI, beta cells are $\sim 1.5$ times more sensitive than alpha cells $(A)$. This might correspond to the beta's roughly twofold greater density of bipolar cell synapses $(B)$. Density of membrane falls sharply with field size for beta cells and modestly for alpha cells. Alpha and beta cell with same field size (ringed pair) have the same membrane area. Open and filled symbols represent, respectively, ON and OFF cells. $C$, Peak sensitivity versus receptive field center diameter. Data replotted from Linsenmeier et al. (1982) with permission. Sensitivity was measured as $1 /\left(\right.$ degree $^{2} \times$ stimulus contrast for a fundamental amplitude of 10 spikes/sec). Open and filled symbols respectively, ON and OFF cells.

and Sterling, 1992; Kolb and Nelson, 1993), the distribution of synapses across the dendritic field must also be dome-like. Assuming electrotonic weighting by the dendritic tree is flat, we hypothesize that the domed distribution of synapses is an important determinant of the Gaussian receptive field center.

Consistent with this hypothesis, compartmental models of central beta (Koch et al., 1982) and central alpha cells (Freed et al., 1992) suggest that their electrotonic weightings are, indeed, flat. The central alpha cell model also plausibly describes the peripheral beta cell because they are virtually the same size (Fig. $8 D$ ). However, peripheral alpha cells are so large that additional modeling is needed to explore whether their electrotonic functions could be flat. The present hypothesis also assumes that the quantal conductance is constant at all dendritic loci. Consistent with this, the bipolar synapses appear similar at all loci. However, even if the number of postsynaptic glutamate receptors at such synapses differed by 10 -fold, this would not be detected by electron microscopy of tissue sections. Therefore, this is another assumption to be explored with a compartmental model (Kier et al., 1995).

Our hypothesis attributes the receptive field center solely to cone bipolar cell synapses, which are presumably glutamatergic and thus excitatory (Massey, 1990; Diamond and Copenhagen, 1993; Cohen and Miller 1994; Cohen et al., 1994). This assumption is reasonable for beta cells where cone bipolar cell synapses constitute as much as $70 \%$ of the input (Kolb, 1979; McGuire et al., 1986; Cohen and Sterling, 1992; Weber et al., 1991) and where amacrine synapses are probably mostly inhibitory (glycine or GABA: Chun and Wässle, 1989; Pourcho and Owczarzak, 1989, 1991; Vardi and Auerbach, 1995). But what about alpha cells where bipolar cell synapses are only $15 \%$ (Kolb, 1979; Freed and Sterling, 1988; cf. Watanabe et al., 1985; 
Kolb and Nelson, 1993)? The alpha cell also collects from the "starburst" cell (Vardi et al., 1989), known to be cholinergic (Masland et al., 1984; Massey and Redburn, 1985) and therefore excitatory to the alpha cell. Since amacrine synapses, like bipolar cell synapses, distribute evenly to the alpha dendritic membrane (Freed and Sterling, 1988; Kolb and Nelson, 1993), the distribution of amacrine excitation should also be dome-like, consistent with the hypothesis that the distribution of postsynaptic membrane across the dendritic field determines sensitivity across the center of the receptive field.

\section{Ganglion cell peak sensitivity corresponds to synaptic density in the dendritic field}

Figure $8 C$, replotted from Linsenmeier et al. (1982) shows that: (1) ON and OFF beta cells are equally scnsitive, and so are ON and OFF alpha cells; (2) beta cells are much more sensitive than alpha cells; (3) peak sensitivity declines with center diameter, sharply for beta cells, and more modestly for alpha cells. For comparison, Figure $8 B$ shows the density of synapses in the dendritic field for ganglion cells in the present study. The two data sets correspond almost perfectly, suggesting, prima facie, the anatomical wiring as the underlying cause of the physiology. Specifically, we hypothesize that a ganglion cell's peak sensitivity is set by the density of synapses in its dendritic field. This elaborates upon the observations of Creutzfeldt et al. (1970) that related dendritic density per unit area in the dendritic field to sensitivity across the receptive center (see their Fig. 1).

This seems to account simply for the differences between cells of the same type. Also, the beta cell compared to the alpha cell, has at all loci both a twofold greater density of bipolar cell synapses on the membranc and a greater density of membrane in the dendritic field. These two factors together might explain the beta's greater peak sensitivity. Of course, these matches could be mere coincidence, masking a more complex explanation. Both hypotheses assume that the effect of each synapse is the same for cells of different size and type. The hypotheses take no account of inevitable biophysical differences (such as input resistance) between cells of markedly different size. Before these simple hypotheses based on circuitry could be accepted, they must be evaluated by compartmental modeling, and that is the subject of another article (Kier et al., 1995).

\section{References}

Adams JC (1981) Heavy metal intensification of DAB-based HRP reaction product. J Histochem Cytochem 29:775.

Boycott BB, Wässle H (1974) The morphological types of ganglion cells of the domestic cat's retina. J Physiol (Lond) 240:397-419.

Calkins DJ, Schein SJ, Tsukamoto Y, Sterling P (1994) M and L cones in macaque fovea connect to midget ganglion cells by different numbers of excitatory synapses. Nature 371:70-72.

Chun MH, Wässle H (1989) GABA-like immunoreactivity in the cat retina: electron microscopy. J Comp Neurol 279:55-67.

Cleland BG. Harding TH, Tulunay-Keesey U (1979) Visual resolution and receptive field size: examination of two kinds of cat retinal ganglion cell. Science 205:1015-1017.

Cohen E, Sterling P (1990) Convergence and divergence of cones onto bipolar cells in the central area of cat retina. Philos Trans R Soc Lond [Biol] 330:323-328.

Cohen E, Sterling P (1991) Microcircuitry related to the receptive field center of the ON beta ganglion cell. J Neurophysiol 65:352-359.

Cohen E, Sterling P (1992) Parallel circuits from cones to the ON beta ganglion cell. Eur J Neurosci 4:506-520.

Cohen ED, Miller RF (1994) The role of NMDA and non-NMDA excitatory amino acid receptors in the functional organization of primate retinal ganglion cells. Vis Neurosci 11:317-332.

Cohen ED, Zhou ZJ, Fain GL (1994) Ligand-gated currents of alpha and beta ganglion cells in the cat retinal slice. $J$ Neurophysiol 72: $1260-1269$.

Creutzfeldt OD, Sakmann B, Scheich H, Korn A (1970) Sensitivity distribution and spatial summation within receptive-field center of retinal on-center ganglion cells and transfer function of the retina. J Neurophysiol 33:654-671.

Dacey DM, Brace S (1992) A coupled network for parasol but not midget ganglion cells in the primate retina. Vis Neurosci 9:279-290.

Diamond JS, Copenhagen DR (1993) The contribution of NMDA and non-NMDA receptors to the light-evoked input-output characteristics of retinal ganglion cells. Neuron 11:1-20.

Dowling JE, Boycott BB (1965) Neural connections of the retina: fine structure of the inner plexiform layer. Cold Spring Harb Symp 30: $393-402$.

Enroth-Cugell C, Robson JG (1966) The contrast sensitivity of retinal ganglion cells of the cat. J Physiol (Lond) 187:517-552.

Freed MA, Sterling P (1988) The ON alpha ganglion cell of the cat retina and its presynaptic cell types. J Neurosci 8:2303-2320.

Freed MA, Smith RG, Sterling P (1992) Computational model of the ON alpha ganglion cell receptive field based on bipolar cell circuitry. Proc Natl Acad Sci USA 89:236-240.

He S (1994) Ph.D. Thesis: Further investigations of the direction-selective ganglion cells of the rabbit retina. Australian National University,

Kier CK, Buchsbaum G, Smith RG, Sterling P (1995) How the spatiotemporal distribution of transmitter quanta determines ganglion cell sensitivity. Submitted.

Koch C, Poggio T, Torre V (1982) Retinal ganglion cells: a functional interpretation of dendritic morphology. Philos Trans R Soc Lond [Biol] 298:227-264.

Kolb $H$ (1979) The inner plexiform layer in the retina of the cat: electron microscopic observations. J Neurocytol 8:295-329.

Kolb H, Nelson R (1993) OFF-alpha and OFF-beta ganglion cells in cat retina: II. Neural circuitry as revealed by electron microscopy of HRP stains. J Comp Neurol 329:85-110.

Linsenmeier RA, Frishman LJ, Jakiela HG, Enroth-Cugell C (1982) Receptive field properties of $\mathrm{X}$ and $\mathrm{Y}$ cells in the cat retina derived from contrast sensitivity measurements. Vision Res 22:1173-1183.

Masland RH, Mills JW, Cassidy C (1984) The funcions of acetylcholine in the rabbit retina. Proc $\mathbf{R}$ Soc Lond [Biol] 223:121-139.

Massey SC (1990) Cell types using glutamate as a neurotransmitter in the vertebrate retina. In: Progress in retinal research (Osborne $\mathrm{N}$, Chader J, eds), pp 399-425. Boston: Pergamon.

Massey SC, Redburn DA (1985) Light evoked release of acetylcholine in response to a single flash: cholinergic amacrine cells receive $\mathrm{ON}$ and OFF input. Brain Res 328:374-377.

McGuire BA, Stevens JK, Sterling P (1984) Microcircuitry of bipolar cells in cat retina. J Neurosci 4:2920-2938.

McGuire BA, Stevens JK, Sterling $\mathbf{P}$ (1986) Microcircuitry of beta ganglion cells in the cat retina. J Neurocytol 6:907-918.

Nelson R, Kolb H, Freed MA (1993) OFF-alpha and OFF-beta ganglion cells in cat retina. I: Intracellular electrophysiology and HRP stains. J Comp Neurol 329:68-84.

Peichl L, Wässle $\mathbf{H}$ (1979) Size, scatter and coverage of ganglion cell receptive field centres in the cat retina. J Physiol (lond) 291:117141.

Peichl L, Wässle H (1983) The structural correlate of the receptive field centre of alpha ganglion cells in the cat retina. J Physiol (Lond) 341:309-324.

Pourcho RG, Owczarzak MT (1989) Distribution of GABA immunoreactivity in the cat retina: a light- and electron-microscopic study. Vis Neurosci 2:425-435.

Pourcho RG, Owczarzak MT (1991) Connectivity of glycine immunoreactive amacrine cells in the cat retina. J Comp Neurol 307:549561.

Pu M, Berson DM, Pan T (1994) Structure and function of retinal ganglion cells innervating the cat's geniculate wing: an in vitro study. J Neurosci 14:4338 4358.

Rao-Mirotznik R, Harkins AB, Buchsbaum G, Sterling P (1995) Mammalian rod terminal: architecture of a binary synapse. Neuron 14: 561-569.

Rodieck RW, Stone J (1965) Analysis of receptive fields of cat retinal ganglion cells. J Neurophysiol 28:833-849.

Smith RG (1987) Montage: a system for three-dimensional reconstruction by personal computer. J Neurosci Methods 21:55-69. 
Stanford LR (1987) X-cells in the cat retina: relationships between the morphology and physiology of a class of cat retinal ganglion cells. $\mathbf{J}$ Neurophysiol 58:940-964.

Steinberg RH, Reid M, Lacy PL (1973) The distribution of rods and cones in the retina of the cat (Felis domesticus). J Comp Neurol 148: $229-248$

Sterling P, Freed MA, Smith RG (1988) Architecture of rod and cone circuits to the ON beta ganglion cell. J Neurocytol 8:623-642.

Stevens JK, Davis TL, Friedman N, Sterling P (1980a) A systematic approach to reconstructing microcircuitry by electron microscopy of serial sections. Brain Res Rev 2:265-293.

Stevens JK, McGuire BA, Sterling P (1980b) Toward a functional architecture of the retind: serial reconstruction of adjacent ganglion cells. Science 207:317-319.

Tauchi M, Masland RH (1985) Local order among the dendrites of an amacrine cell population. J Neurosci 5:2494-2501.

Tsukamoto Y, Sterling P (1991) Spatial summation by ganglion cells: some consequences for the efficient encoding of natural scenes. Neurosci Res Suppl 15:5185-5198.

Tsukamoto Y, Smith RG, Sterling P (1990) "Collective coding" of correlated cone signals in the retinal ganglion ccll. Proc Natl Acad Sci USA 87:18-60-1864.

Tsukamoto Y, Masarachia P, Schein SJ, Sterling P (1992) Gap junctions between the pedicles of macaque foveal cones. Vision Res 32:1809_ 1815.

Vaney DI (1991) Many diverse types of retinal neurons show tracer coupling when injected with biocytin or Neurobiotin. Neurosci Lett $125: 187-190$.

Vaney DI (1994) Territorial organization of direction-selective ganglion cells in rabbit retina. J Neurosci 14:6301-6316.

Vardi N, Auerbach P (1995) Specific cell types in cat retina express different forms of glutamic acid decarboxylase. J Comp Neurol 351: 374-384.

Vardi N, Masarachia P, Sterling P (1989) Structure of the starburst amacrine network and its association with alpha ganglion cells. J Comp Neurol 288:601-611.

Watanabe M, Fukuda Y, Hsiao C-F, Ito H (1985) Electron microscopic analysis of amacrine and bipolar cell inputs on $\mathrm{Y}-, \mathrm{X}$ - and $\mathrm{W}$-cells in the cat retina. Brain Res 358:229-240.

Weber AJ, McCall MA, Stanford LR (1991) Synaptic inputs to physiologically identified retinal X-cells in the cat. J Comp Neurol 314: $350-366$.

Wiesel TN (1960) Receptive fields of ganglion cells in the cat's retina J Physiol (Lond) 153:583-594.

Williams DR (1992) Tutorials in optics. In: OSA annual meeting publication, Photoreceptors sampling and aliasing in human vision (Moore DT, ed), pp 15-28. OSA.

Williams RW, Cavada C, Reinoso-Suarez F (1993) Rapid evolution of the visual system: a cellular assay of the retina and dorsal lateral geniculate nucleus of the spanish wildcat and the domestic cat. J Neurosci 13:208-228.

Yang G, Masland RH (1994) Receptive fields and dendritic structure of directionally selective retinal ganglion cells. J Neurosci 14:52675280 . 